\title{
GENERALIZATION OF $K$-DIVERGENCE AND RELATED MEANS
}

\author{
M. ANWAR, G. FARID AND J. PEČARIĆ
}

Abstract. In this paper, we give a generalization of $K$-divergence measure and related results by using some log-convexity criteria. Also we give related Cauchy means and prove monotonicity of these means.

Mathematics subject classification (2010): 26A46, 26A48.

Keywords and phrases: Convex function, K-divergence, J-divergence, log-convexity, Cauchy means.

\section{REFERENCES}

[1] M. Anwar And J. PeČArić, New Means of Cauchy's type, J. Inequal. and Appl. Vol. 2008 (2008), Article ID 163202.

[2] M. Anwar, N. Latif And J. PeČArić, Cauchy Means of the Popoviciu type, J. Inequal. and Appl. Vol. 2009 (2009), Article ID 628051.

[3] J. Burbea And C. R. Rao, On Convexity Of Some Divergence Measure Based On Entropy Functions, IEEE Transactions on Information Theory vol. IT-28, 3 (May 1982).

[4] R. G. Gallager, Information Theory and Reliable Communication, Willy, New York, 1968.

[5] S. Huss AIn, On Jensen's and related Inequalities, Thesis.

[6] R. C. LEWONTON, The apportionment of human diversity, Evolutionary Biology 6 (1973), 381-398.

[7] J. E. PeČarić, F. Proschan and Y. C. Tong, Convex functions, Partial Orderings and Statistical Applications, Academic Press, New York, 1992.

[8] E. C. Pielou, Ecological Diversity, Willy, New York, 1975.

[9] C. R. RAO, Diversity and dissimilarity coefficients: a unified approach, University of Pittsburgh Tech. Rep. 80-10, 1980. 